\title{
Isolation and Partial Characterization of Three Escherichia coli Mutants with Altered Transfer Ribonucleic Acid Methylases
}

\author{
MARTIN G. MARINUS, ${ }^{1}$ N. RONALD MORRIS, DIETER SOLL, ${ }^{*}$ AND TAI C. KWONG \\ Department of Pharmacology, College of Medicine and Dentistry of New Jersey, Rutgers Medical School, \\ Piscataway, New Jersey 08854, and Department of Molecular Biophysics and Biochemistry, Yale University, \\ New Haven, Connecticut 06520*
}

Received for publication 20 January 1975

\begin{abstract}
Seven transfer ribonucleic acid (tRNA) methylase mutants were isolated from Escherichia coli K-12 by examining the ability of RNA prepared from clones of unselected mutagenized cells to accept methyl groups from $S$-adenosylmethionine catalyzed by crude enzymes from wild-type cells. Five of the mutants had an altered uracil-tRNA methylase; consequently their tRNA's lacked ribothymidine. One mutant had tRNA deficient in 7-methylguanosine, and one mutant contained tRNA lacking 2-thio-5-methylaminomethyluridine. The genetic loci of the three tRNA methylase mutants were distributed over the $E$. coli genome. The mutant strain deficient in 7-methylguanosine biosynthesis showed a reduced efficiency in the suppression of amber mutations carried by T4 or $\lambda$ phages.
\end{abstract}

Transfer ribonucleic acid (tRNA) from many organisms contains a great variety of modified nucleotides $(12,23,27)$. Most abundant among them are the methylated nucleotides. In all known cases they are formed in a post-transcriptional modification of macromolecular tRNA or precursor tRNA by tRNA-specific methylases that use $S$-adenosylmethionine (SAM) as methyl donor (16). To date only a few tRNA methylases have been studied in detail partly due to the lability of these enzymes and partly due to the lack of defined RNA substrates (e.g., 32).

Bacterial mutants defective in certain tRNA methylases would be very desirable. Not only would they facilitate enzymatic studies of these enzymes, but they might also reveal the biological role of a specific methylated base in tRNA. So far only two tRNA methylase mutants are known. One is a mutant yeast strain in which the tRNA lacks 2-dimethylguanosine (25). The other is an Escherichia coli mutant unable to form ribothymidine in tRNA (4). Despite the specific undermethylation in their tRNA's, both strains grow normally $(5,25,34)$. However, this gross observation does not rule out subtle changes in their metabolism or its regulation.

Björk and Isaksson (4) isolated the $E$. coli tRNA methylase mutant by in vitro screening of mutagenized colonies for methyl-deficient RNA. Using a similar, more sensitive proce-

\footnotetext{
${ }^{1}$ Present address: Department of Pharmacology, University of Massachusetts Medical Center, Worcester, Mass. 01605.
}

dure, we had earlier identified a number of deoxyribonucleic acid (DNA) methylase mutants (20). During that work we also discovered a number of RNA methylase mutants. In this paper we describe the isolation of three different tRNA methylase mutants, each defective in the formation of one methylated nucleoside, namely, 7-methylguanosine, 2-thio-5methylaminomethyluridine, and ribothymidine.

\section{MATERIAL AND METHODS}

Bacterial strains and bacteriophages. The bacterial strains used in this study are described in Table 1. T4 amber phages B17, N65 (7) and E605, H39X (8) were obtained from $\mathrm{S}$. Champe and J. Karam, and $\lambda$ gam-210 (35) was obtained from A. Skalka.

Media and reagents. Complete medium consisted of $20 \mathrm{~g}$ of brain heart infusion (Difco) per liter plus 10 $\mu \mathrm{g}$ of thymine per $\mathrm{ml}$ solidified when required with $1.6 \%$ agar. M9 (1) was the minimal medium used and was supplemented with the required growth factors (2). Streptomycin was added at a final concentration of $200 \mu \mathrm{g} / \mathrm{ml}$.

[methyl-14C]SAM (50 $\mathrm{mCi} / \mathrm{mmol})$, [methyl${ }^{3} \mathrm{H}$ ]SAM (379 $\left.\mathrm{mCi} / \mathrm{mmol}\right),\left[{ }^{3} \mathrm{H}\right]$ phenylalanine $(5.1$ $\mathrm{Ci} / \mathrm{mmol})$, and $\left[{ }^{3} \mathrm{H}\right.$ ]glutamic acid $(20 \mathrm{Ci} / \mathrm{mmol})$ were obtained commercially. Ribonuclease (RNase) T2 (Sankyo Co.) and bacterial alkaline phosphatase were obtained from Calbiochem and Worthington Biochemical Corp., respectively. A sample of 2-thio-5methylaminomethyluridine 3 ' -phosphate was a generous gift of S. Nishimura.

Mutagenesis. Log-phase cultures of strain GM1 were treated with $N$-methyl- $N$-nitro- $N$-nitrosoguanidine as described by Adelberg et al. (3). 
TABLE 1. Description of bacterial strains

\begin{tabular}{|c|c|c|c|}
\hline Strain & Sex & Relevant genotype & Source \\
\hline GM1 & $\mathbf{F}^{-}$ & trm $^{+}$ & $\begin{array}{l}\text { Marinus and } \\
\text { Morris (20) }\end{array}$ \\
\hline GM18 & $\mathrm{F}^{-}$ & $\operatorname{trm} B 1^{a}$ & $\begin{array}{l}\mathrm{NG}^{b} \text { treatment of } \\
\text { GM1 }\end{array}$ \\
\hline GM19 & $\mathbf{F}^{-}$ & $\operatorname{trm} C 2^{a}$ & $\begin{array}{l}\text { NG treatment of } \\
\text { GM1 }\end{array}$ \\
\hline GM20-24 & $\mathbf{F}^{-}$ & $\operatorname{trm} A 11-\operatorname{trm} A 15^{a}$ & $\begin{array}{l}\text { NG treatment of } \\
\text { GM1 }\end{array}$ \\
\hline Hfr 3000 & $\mathrm{Hfr}$ & thi-1 rel-1 $\lambda^{-}$ & CGSC $^{c}$ \\
\hline KL16 & $\mathrm{Hfr}$ & thi-1 rel-1 $\lambda^{-}$ & CGSC \\
\hline KL154 & Hfr & $\begin{array}{l}\text { purF1 mtl-2 } 2 x y l-7 \\
\text { gal-6 lac Y1 or } \\
\text { Z4 }\end{array}$ & CGSC \\
\hline KL983 & Hfr & $\begin{array}{l}x y l-7 \text { lacY1 } \\
\text { mglPl }\end{array}$ & CGSC \\
\hline PK191 & $\mathrm{Hfr}$ & $\begin{array}{l}\text { thi-1 } 1 \text { (proB-lac })_{\times 111} \\
\quad \text { sup }-56\end{array}$ & CGSC \\
\hline $\mathrm{C} 6$ & Hfr & $\begin{array}{l}\text { cysG49 metB1 } \\
\text { rel-1 }(\lambda)\end{array}$ & Harris et al. (13) \\
\hline W3679 & $\mathbf{F}^{-}$ & $\operatorname{argC} 24 \operatorname{galT} 23 \lambda^{-}$ & CGSC \\
\hline KL356 & $\mathbf{F}^{-}$ & $\operatorname{trmA} 14 \operatorname{galT} 23 \lambda^{-}$ & $\begin{array}{l}\mathrm{P} 1(\mathrm{GM} 23) \times \\
\mathrm{W} 3679 \rightarrow \mathrm{Arg}^{+}\end{array}$ \\
\hline
\end{tabular}

${ }^{a}$ In addition, these strains contain the following mutations: thr-1 leu-6 proA2 his-4. metB1 lacY1 galK2 ara-14 xyl-5 mtl-1 str-31 tsx-33 thi-1 thyA12 drm-6 supE44 rel ${ }^{+}$.

${ }^{b} \mathrm{NG}$, Nitrosoguanidine.

CGSC, E. coli Genetic Stock Center. Yale University. New Haven, Conn.

Isolation of mutants. Single colonies, obtained after mutagenesis, were inoculated in $2 \mathrm{ml}$ of complete medium and grown at $30 \mathrm{C}$ overnight. The next day, the cultures were pooled in groups of 10 and an equal volume of fresh medium was added $(40 \mathrm{ml}$ total). After growth had commenced at $30 \mathrm{C}$, the temperature was shifted to $42 \mathrm{C}$. The cultures were incubated for $1 \mathrm{~h}$ and the cells were harvested. Total nucleic acids were prepared essentially by the method of Marmur (21) except that the RNase and subsequent steps were omitted. Methyl group incorporation into RNA (and also into DNA; see ref. 20) was determined as described below. If methyl acceptor activity was found, the 10 colonies were retested in groups of five and then individually.

Preparation of methylating enzymes (used for screening mutagenized colonies). Late log-phase cultures of strain GM1 grown in complete medium at $30 \mathrm{C}$ were harvested and washed twice with 0.01 $\mathrm{M}$ tris(hydroxymethyl)aminomethane (Tris) ( $\mathrm{pH} \mathrm{7.8)-}$ $0.001 \mathrm{M}$ ethylenediaminetetraacetic acid (EDTA). The cells were ground with twice their wet weight of alumina and extracted with 5 volumes of $0.04 \mathrm{M}$ Tris (pH 7.8)-0.001 M EDTA-0.001 M dithiothreitol$10 \%$ (vol/vol) glycerol. The crude extract was clarified by 2 centrifugations at $12,000 \times g$ for $10 \mathrm{~min}$, dispensed into tubes, and stored frozen at $-60 \mathrm{C}$. Such frozen extracts are stable for at least 6 months.

Assay of methyl group incorporation into RNA. The reaction mixture $(0.25 \mathrm{ml})$ contained, per milli-

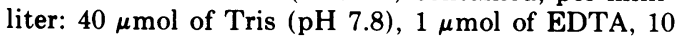
$\mu \mathrm{mol}$ of $\mathrm{MgSO}_{4}, 20 \mu \mathrm{mol}$ of $\mathrm{NH}_{4} \mathrm{Cl}, 6.3 \mathrm{nmol}$ of [methyl ${ }^{3} \mathrm{H}$ ]SAM, substrate RNA, and 0.25 to $1 \mathrm{mg}$ of methylase enzyme preparation. The reaction time was $30 \mathrm{~min}$ at $37 \mathrm{C}$. The reaction was stopped by the addition of $0.2 \mathrm{ml}$ of $25 \%$ sodium lauryl sulfate and water to a final volume of $2 \mathrm{ml}$, followed by heating at $60 \mathrm{C}$ for $10 \mathrm{~min}$. Sodium perchlorate was added to a final concentration of $1 \mathrm{M}$ and the mixture was shaken with an equal volume of chloroform/isoamyl alcohol (24:1). The aqueous phase was removed after centrifugation and cooled in ice, and the nucleic acids were precipitated with $0.5 \mathrm{M}$ perchloric acid and washed three times with cold $0.5 \mathrm{M}$ perchloric acid. The precipitate was suspended in $0.5 \mathrm{M} \mathrm{NaOH}$ and heated at $60 \mathrm{C}$ for $10 \mathrm{~min}$ to hydrolyze RNA. After cooling, the solution was precipitated with $0.5 \mathrm{M}$ perchloric acid and centrifuged. Portions of the supernatant fluid $(0.2 \mathrm{ml})$ were dissolved in scintillation medium consisting of $4 \mathrm{~g}$ of Omnifluor (New England Nuclear Corp), $667 \mathrm{ml}$ of toluene, and $330 \mathrm{ml}$ of absolute ethanol.

Genetic procedures. The Hfr strains, conjugation and transduction procedures, and methods for the selection of recombinants or transductants have been described in detail elsewhere (19). Ten recombinants or transductants from each cross were scored for trm by measuring the methyl group incorporation into RNA as described above.

Plating of bacteriophages. The plating efficiencies were determined as described by Adams (1).

Preparation of tRNA methylases. tRNA methylases (used for characterization of mutants) from strain GM1 were prepared by a procedure that was essentially the method B used by Schaefer et al. (26), except that the ammonium sulfate fractionation step was omitted. Fractions containing the tRNA methylase activities that had been eluted from a diethylaminoethyl-cellulose column by $0.2 \mathrm{M} \mathrm{NaCl}$ were designated pool I, whereas those eluted by $0.3 \mathrm{M} \mathrm{NaCl}$ (predominantly uracil-tRNA methylase, see reference 26) were called pool II.

Preparation of tRNA and aminoacyl-tRNA synthetases. The preparation of unfractionated tRNA from strains GM1, GM18, GM19, GM23, C6, and from Mycoplasma sp. (Kid) (14) and the preparation of aminoacyl-tRNA synthetases from strain GM1 were performed as reported previously (30).

Preparation of rRNA. Ribosomal RNA (rRNA) from strains GM1, GM18, GM19, and GM23 was prepared by the procedure of Nichols and Lane (22) followed by gel filtration on Sephadex G-200.

Assay of methyl acceptance of mutant tRNA or rRNA. Each assay mixture $(0.2 \mathrm{ml})$ contained, per milliliter: $50 \mu \mathrm{mol}$ of Tris $(\mathrm{pH} 8.0), 5 \mu \mathrm{mol}$ of magnesium chloride, $6 \mu \mathrm{mol}$ of 2 -mercaptoethanol, $2.5 \mu \mathrm{Ci}$ of $\left[\right.$ methyl $\left.{ }^{14} \mathrm{C}\right] \mathrm{SAM}, 1.0$ to 7.5 absorbancy units at $260 \mathrm{~nm}$ of tRNA or rRNA, and $1.25 \mathrm{mg}$ of pool I methylase or $0.75 \mathrm{mg}$ of pool II methylase. The reaction was allowed to proceed at $37 \mathrm{C}$. Samples were removed at various time intervals and assayed for acid-precipitable radioactivity by the filter paper technique.

Preparation of [methyl- ${ }^{14} \mathbf{C}$ ] tRNA. Large-scale preparation of [methyl $\left.{ }^{14} \mathrm{C}\right]$ tRNA for nucleotide analysis was performed by scaling up the methyl acceptance assay. [methyl $\left.-{ }^{14} \mathrm{C}\right] \mathrm{tRNA}$ was recovered by phenol extraction of the reaction mixture and then concentrated by alcohol precipitation and extensively 
dialyzed against glass-distilled water. Double-labeled [methyl $\left.-{ }^{14} \mathrm{C}\right]-\left[{ }^{3} \mathrm{H}\right] \mathrm{Glu}-\mathrm{tRNA}$ was prepared by aminoacylation (14) of [methyl-14C]tRNA with $\left[{ }^{3} \mathrm{H}\right]$ glutamic acid.

Enzymatic digestion of tRNA. [methyl $\left.-{ }^{14} \mathrm{C}\right] \mathrm{tRNA}$ (approximately 30 absorbancy units at $260 \mathrm{~nm}$ ) was digested with RNase T2 (25 units) in $0.1 \mathrm{ml}$ of $0.02 \mathrm{M}$ ammonium acetate $(\mathrm{pH} 4.5)$ at $37 \mathrm{C}$ for 4 or $24 \mathrm{~h}$ (for $m^{7} G$ ). The digest was separated by two-dimensional chromatography as described below. Nucleotides were dephosphorylated with bacterial alkaline phosphatase $(10 \mu \mathrm{g})$ in $10 \mu \mathrm{l}$ of $10 \mathrm{mM}$ Tris $(\mathrm{pH} 8.0)$ for $3 \mathrm{~h}$ at $37 \mathrm{C}$.

Chromatography and electrophoresis. Twodimensional chromatography in the descending fashion was conducted at room temperature with Whatman no. 1 or $3 \mathrm{MM}$ paper. The solvent systems (vol/vol) were: isobutyric acid/0.5 M ammonium hydroxide (5:3) (solvent I); and 2-propanol/concentrated $\mathrm{HCl} /$ water $(68: 17.6: 14.4)$ (solvent II). Cellulose plates $(20$ by $20 \mathrm{~cm}$ ) were used for thin-layer chromatography and electrophoresis. The solvent systems for thin-layer chromatography were $(\mathrm{vol} / \mathrm{vol})$ : solvents I and II; 2-propanol/water/ammonium hydroxide (7:2:1) (solvent III); and 1-butanol/acetic acid/water (5:3:2) (solvent IV).

Thin-layer electrophoresis was conducted in $20 \mathrm{mM}$ potassium phosphate $(\mathrm{pH} 7.0)$ at $400 \mathrm{~V}$ for $1 \mathrm{~h}$.

Column chromatography. Affinity column chromatography on polyacrylamide-bound yeast $\mathrm{tRNA} \mathrm{A}^{\text {Phe }}$ was performed according to Grosjean et al. (10). Unfractionated [methyl- $\left.{ }^{14} \mathrm{C}\right]-\left[{ }^{3} \mathrm{H}\right] \mathrm{Glu}-\mathrm{tRNA}$ from strain GM19 was loaded very slowly $(2.7 \mathrm{ml} / \mathrm{h})$ at $0 \mathrm{C}$ onto the column ( 1 by $1 \mathrm{~cm}$; resin has $5 \mathrm{mg}$ of tRNA attached), which had been previously equilibrated with buffer A ( $10 \mathrm{mM}$ sodium acetate $[\mathrm{pH} 5.4$ V10 $10 \mathrm{mM}$ magnesium sulfate/ $1 \mathrm{M}$ sodium chloride). After washing the column with $20 \mathrm{ml}$ of the same buffer, elution of Glu-tRNA was effected at $30 \mathrm{C}$ by buffer B $(10 \mathrm{mM}$ sodium acetate $[\mathrm{pH} 5.4 \mathrm{~V} / \mathrm{M}$ sodium chloride $/ 10 \mathrm{mM}$ EDTA) at a flow rate of $10 \mathrm{ml} / \mathrm{h}$. Fractions of $0.5 \mathrm{ml}$ were collected and a sample from each fraction was measured for ${ }^{3} \mathrm{H}$ and ${ }^{14} \mathrm{C}$ radioactivity. The material in fractions 25 to 33 (see Fig. 3A) was pooled and used for RPC-5 chromatography.

Reversed-phase chromatography (RPC-5) was performed according to Kelmers and Heatherly (15). The pooled fractions of $\left[\right.$ methyl $\left.-{ }^{14} \mathrm{C}\right]-\left[{ }^{3} \mathrm{H}\right] \mathrm{Glu}-\mathrm{tRNA}$ (see Fig. 3A) were applied to an RPC- 5 column ( 0.6 by 30 $\mathrm{cm}$ ) that had been previously equilibrated with $0.4 \mathrm{M}$ $\mathrm{NaCl} / 10 \mathrm{mM} \mathrm{MgCl}_{2} / 10 \mathrm{mM}$ sodium acetate $(\mathrm{pH}$ 4.5)/2 mM 2-mercaptoethanol. Elution was carried out at $22 \mathrm{C}$ with a linear gradient $(100 \mathrm{ml})$ of $\mathrm{NaCl}$ $(0.45$ to $0.8 \mathrm{M})$. One-milliliter fractions were collected every $2 \mathrm{~min}$.

\section{RESULTS}

Isolation of mutants. When RNA and a preparation of RNA-methylating enzymes from the same bacterial strain are incubated with SAM, no transfer of methyl groups is observed, since the RNA is already fully methylated in vivo. However, if methyl-deficient RNA (obtained by starving of a rel- methionine auxo- troph for its required amino acid) is used, methyl group transfer does occur (9). Similarly, mutant strains lacking a specific methylated base in RNA will accept methyl groups when incubated with SAM and methylating enzymes from wild-type cells $(4,25)$. To produce mutants, strain GM1 was mutagenized with nitrosoguanidine. Fifteen hundred nitrosoguanidine-treated survivors were taken at random and screened for RNA methyl acceptor activity with a crude RNA methylase preparation from strain GM1 and [methyl- $\left.{ }^{3} \mathrm{H}\right] \mathrm{SAM}$ as methyl donor. Seven strains were detected that showed methyl incorporation ranging from 1,164 to 5,256 counts/min into the RNA (isolated from $40-\mathrm{ml}$ cultures of each strain). When RNA from the wild strain was tested as a control, it also accepted some methyl groups (an average of 635 counts $/ \mathrm{min}$ ). Therefore, under normal growth conditions RNA is slightly undermethylated. This has also been observed by Björk and Isaksson (4). After treatment with RNase A, all the radioactivity in the methylated mutant RNA was rendered acid soluble. No methyl group incorporation into DNA was detected.

A preliminary characterization showed that strains GM20, GM21, GM22, GM23, and GM24 all had the same lesion. Strain GM23 was chosen for further study.

Preliminary mapping of the tRNA methylase-deficient character. Mapping of the tRNA methylase genes presents certain difficulties. In $\mathrm{trm}^{+} \times \mathrm{trm}^{-}$crosses, it is not possible to select for $\mathrm{Trm}^{+}$recombinants, since no phenotypic trait has yet been discovered that allows for the direct selection of such recombinants. To map the trm genes, an indirect method was used that involved the selection of recombinants prototrophic for a particular genetic marker (e.g., $\mathrm{His}^{+}$, $\mathrm{Met}^{+}$, etc.) and subsequent analysis of the tRNA from the recombinant strains for the presence of the methylated base. This is accomplished by extracting bulk RNA from each recombinant and assaying methyl group incorporation into tRNA catalyzed by crude extract from strain GM1. In view of the tedious procedure, only 10 recombinants from each cross were analyzed, since the aim of the preliminary genetic analysis was to determine whether the trm genes were clustered in a small part of the chromosome or scattered around the genetic map. The results are given in Table 2; the points of origin of the various Hfr strains are shown in Fig. 1.

When strain GM18 was mated with $\mathrm{Hfr}$ PK191 and Thy $^{+}$recombinants were selected, none of them were $\mathrm{trm}^{+}$(Table 2). The trm mutation, therefore, does not lie between the origin of Hfr PK191 and thyA. When strain 
TABLE 2. Location of trm mutations on the $E$. coli K-12 genetic map

\begin{tabular}{|c|c|c|c|}
\hline Cross $^{a}$ & $\begin{array}{l}\text { Selected } \\
\text { marker }\end{array}$ & $\begin{array}{c}\text { Unselected } \\
\text { marker }\end{array}$ & $\begin{array}{c}\text { Linkage } \\
(\%)\end{array}$ \\
\hline \multirow[t]{3}{*}{$\mathrm{AB} 259 \times \mathrm{GM} 18$} & $\mathrm{Thr}^{+}$Leu ${ }^{*}$ & $\operatorname{trmB1} 1^{+}$ & 50 \\
\hline & ProA $^{+}$ & $\operatorname{trmB1} 1^{+}$ & 80 \\
\hline & $\mathrm{His}^{+}$ & $\operatorname{trmB1}{ }^{+}$ & 30 \\
\hline PK191 × GM18 & ThyA ${ }^{+}$ & $\operatorname{trmB1} 1^{+}$ & 0 \\
\hline $\mathrm{KL} 154 \times \mathrm{GM} 18$ & $\mathrm{Thr}^{+} \mathrm{Leu}^{+}$ & $\operatorname{trm} \mathrm{B1}^{+}$ & 40 \\
\hline PK191 × GM19 & ThyA $^{+}$ & $\operatorname{trmC1} 1^{+}$ & 50 \\
\hline $\mathrm{KL} 16 \times \mathrm{GM} 19$ & $\mathrm{His}^{+}$ & $\operatorname{trmC1} 1^{+}$ & 30 \\
\hline KL983 × GM19 & $\mathrm{His}^{+}$ & $\operatorname{trmC1} 1^{+}$ & 0 \\
\hline $\mathrm{AB} 259 \times \mathrm{GM} 19$ & $\mathrm{His}^{+}$ & $\operatorname{trmCl} 1^{+}$ & 0 \\
\hline KL154 × GM19 & $\mathrm{Thr}^{+} \mathrm{Leu}^{+}$ & $\operatorname{trmC1} 1^{+}$ & 0 \\
\hline KL154 × GM 23 & $\mathrm{Thr}^{+} \mathrm{Leu}^{+}$ & $\operatorname{trmA14} 4^{+}$ & 50 \\
\hline KL154 × GM23 & $\mathrm{MetB}^{+}$ & $\operatorname{trmA14^{+}}$ & 80 \\
\hline $\mathrm{AB} 259 \times \mathrm{GM} 23$ & $\mathrm{His}^{+}$ & $\operatorname{trmA14} 4^{+}$ & 0 \\
\hline PK191 × GM23 & ThyA+ & $\operatorname{trmA14} 4^{+}$ & 0 \\
\hline
\end{tabular}

${ }^{a}$ Donor and recipient cells were mated at a ratio of 1:20 for $60 \mathrm{~min}$ at $37 \mathrm{C}$, after which the cultures were blended for $1 \mathrm{~min}$, diluted, and plated in soft agar overlays on selective media. Ten recombinants from each cross were scored for trm as described in the text.

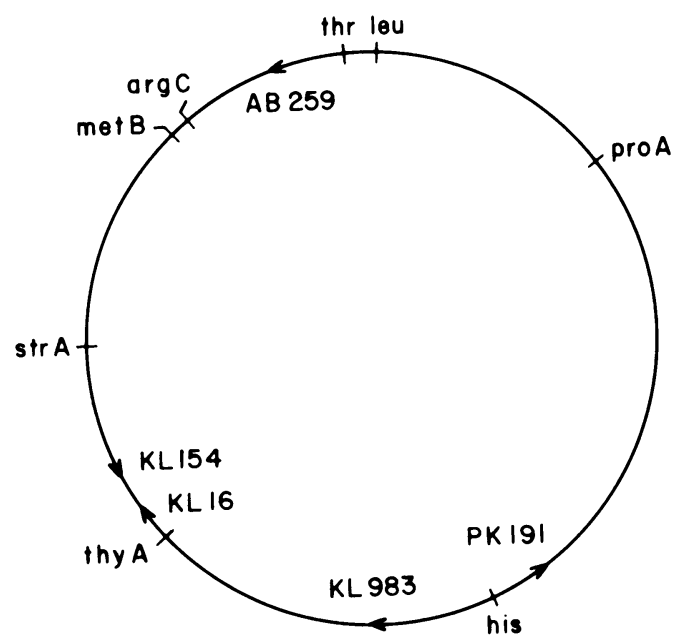

Fig. 1. Genetic map of E. coli K-12 (after Taylor and Trotter [33]) showing pertinent genetic markers on the outside of the circle and the points of origin of various Hfr strains (17) on the inside of the circle.

GM18 was mated with Hfr KL154 $\left(\mathrm{Thr}^{+} \mathrm{Leu}^{+}\right.$ selection) or Hfr AB259 ( $\mathrm{His}^{+}$selection), some of the selected recombinants were $\mathrm{trm}^{+}$, which means that the trm mutation must lie between the origins of Hfr AB259 and Hfr PK191. To ascertain the position of the trm gene more precisely, Hfr AB259 was mated with strain GM18 and selection was made for $\mathrm{Thr}^{+} \mathrm{Leu}^{+}$, $\mathrm{ProA}^{+}$, and $\mathrm{His}^{+}$recombinants. The data in Table 2 show that $80 \%$ of the $\mathrm{ProA}^{+}$recombinants were also $\mathrm{trm}^{+}$, indicating that the trm mutation in strain GM18 is closely linked to proA.

In contrast, when Hfr PK191 was mated with strain GM19, $50 \%$ of the $\mathrm{Thy}^{+}$recombinants were also $\mathrm{trm}^{+}$. No $\mathrm{trm}^{+}$recombinants were obtained in matings with $\mathrm{Hfr} \mathrm{KL} 154\left(\mathrm{Thr}^{+}\right.$ $\mathrm{Leu}^{+}$selection), KL983 ( $\mathrm{His}^{+}$selection), or AB259 $\left(\mathrm{His}^{+}\right.$selection). These results indicate that the trm mutation in strain GM19 probably lies between the origin of PK191 and thyA. This was confirmed by showing that $30 \%$ of the $\mathrm{His}^{+}$ recombinants, isolated from a cross between $\mathrm{Hfr}$ KL16 and strain GM19, were trm $^{+}$. Since no $\mathrm{trm}^{+}$recombinants were obtained with KL983 as donor strain, the trm mutation in strain GM19 must lie between the points of origin of strains KL16 and KL983.

No $\mathrm{trm}^{+}$recombinants were recovered in crosses involving strain GM23 and Hfr AB259 ( $\mathrm{His}^{+}$selection) or Hfr PK191 (Thy ${ }^{+}$selection). When KL154 was mated with strain GM23, however, $80 \%$ of the $\mathrm{MetB}^{+}$and $50 \%$ of the $\mathrm{Thr}^{+}$ $\mathrm{Leu}^{+}$recombinants were $\mathrm{trm}^{+}$. Björk and Neidhardt (5) have shown that the trmA gene, which specifies a uracil-tRNA methylase, can be cotransduced by $\mathrm{P} 1$ with $\arg H$. A P1 lysate grown on strain GM23 was used to select $\mathrm{Arg}^{+}$transductants from strain W3679, which is $\operatorname{argC} C^{-}$. Among 10 transductants analyzed for the methylase mutation, 8 were found to be Trm ${ }^{-}(80 \%$ cotransduction). Thus, the trm mutation in strain GM23 can be cotransduced at a high frequency with $\arg C$ and appears to be in the trmA gene described by Björk and Neidhardt (5).

The above preliminary genetic analyses are necessarily crude since only 10 recombinants from each cross were examined. In spite of this, it would appear that the trm mutations in strains GM18, GM19, and GM23 are not clustered in a small region of the chromosome but are scattered around the genetic map.

Phenotypic characterization. All the trm strains are able to grow in broth at 30 and $42 \mathrm{C}$ although they display a wide variety of growth rates. Table 3 summarizes the doubling times of the mutant strains and of strain GM1 when grown in LB broth (18).

Strain GM18 grows slowly in broth and requires 4 to 5 days of incubation at $33 \mathrm{C}$ to form colonies on minimal agar. Growth is enhanced by the addition of $1 \%$ Casamino Acids to the minimal medium. Attempts to isolate a derivative of strain GM18 that grows faster in minimal medium were unsuccessful. The slow growth of this strain may be due to the trm mutation or the result of extra mutations induced by the mutagen, nitrosoguanidine, which is known to 
produce several mutations per chromosome (11). However, all recombinant strains with $\mathrm{Trm}^{-}$character from crosses of strain GM18 with the various Hfr strains (see above) showed slow growth.

The trmA strains are quite heterogeneous in their characteristics. Only strain GM23 will grow in minimal medium. However, all are able to grow if Casamino Acids are added to a final concentration of $1 \%$. It is probable that the failure to grow in minimal medium is due to other additional auxotrophic mutations induced by nitrosoguanidine rather than the $\operatorname{trm} A$ mutation, since strain GM23 and the trmA mutant described by Björk and Isaksson (4) show no additional auxotrophy.

Since the trm mutants all contain the supE44 amber suppressor, the efficiency of plating of various $\mathrm{T} 4$ and $\lambda a m b e r$ mutants on the tRNA methylation-defective strains has also been determined. The efficiency of plating of the phages on strains GM19 and GM23 was the same as in the wild-type strain GM1 (data not shown). Strain GM18, however, gave a lower efficiency of plating for some phages (Table 4). The low efficiency of plating may be due to either the loss of 7-methylguanosine in tRNA or to an extraneous mutation induced by nitrosoguanidine (11).

Mutants have altered tRNA methylase activities. Since the majority of methylated nucleosides in RNA are found in tRNA and to a lesser extent in rRNA, we prepared both tRNA

TABLE 3. Doubling time of mutant and wild-type strains

\begin{tabular}{l|l|c}
\hline Strain $^{a}$ & Genotype & $\begin{array}{c}\text { Doubling time } \\
(\mathrm{min})\end{array}$ \\
\hline GM1 & $\operatorname{trm}^{+}$ & 40 \\
GM18 & $\operatorname{trmB1}_{\text {GM19 }}$ & 75 \\
GM10 & trm 11 & 40 \\
GM21 & trmA11 & 45 \\
GM22 & trmA12 $A 13$ & 48 \\
GM23 & trmA14 & 48 \\
GM24 & trmA15 & 40 \\
KL356 & trmA14 & 40 \\
\hline
\end{tabular}

$a$ The strains were grown in LB broth (18) with forced aeration at $37 \mathrm{C}$. and rRNA from strains GM1, GM18, GM19, and GM23. All RNAs were methylated with [methyl $\left.-{ }^{14} \mathrm{C}\right] \mathrm{SAM}$ by using unfractionated tRNA methylases from wild type (GM1). Although there was some methyl group incorporation into rRNA from the trm mutant strains (Table 5), the level of incorporation was negligible and comparable with that of wild-type rRNA. However, there was good methyl acceptance by the tRNA of the mutants (Table 5). We therefore conclude that the mutations in strains GM18, GM19, and GM23 affect tRNA methylases.

Methyl acceptances of the tRNA preparations from the three mutant strains varied from the very low, but in reproducible levels in strains GM18 and GM19 (one methyl group accepted per every 50 and 100 molecules of tRNA, respectively), to the much higher value in strain GM23 (one methyl group accepted per every 1.3 molecules of tRNA) (Table 5). Furthermore, the effectiveness of the different mutant tRNA's to serve as substrate for the two enzyme fractions (pools I and II) varied; tRNA from strains GM18 and GM19 were not methylated by pool II enzymes, whereas tRNA from strain GM23 was an excellent substrate. As controls, tRNA from Mycoplasma sp. (Kid), which has a low content of methylated components and is devoid of ribothymidine (14), and undermethylated tRNA prepared from $E$. coli C6 (13) were also included as controls. The results suggest that GM23 tRNA is deficient in ribothymidine.

Identification of in vitro methylated components. To identify the products of in vitro methylation, the mutant $\left[\right.$ methyl $\left.-{ }^{14} \mathrm{C}\right] \mathrm{tRNA}$ 's were first degraded to the nucleotide level with RNase T2. The hydrolysis products were then resolved by two-dimensional chromatography using solvents I and II. Radioactive regions of the chromatogram were located by autoradiography (Fig. 2). The radioactive materials were recovered for further characterization.

The two-dimensional chromatogram of the nucleotide mixture obtained by RNase T2 digestion of the [methyl $\left.-{ }^{14} \mathrm{C}\right] \mathrm{tRNA}$ from strain GM18 yielded two radioactive spots after autoradiography (Fig. 2A). The radioactive nucleotide, which had a slower mobility in solvent II,

TABLE 4. Efficiency of plating of T4 and גamber mutants

\begin{tabular}{|c|c|c|c|c|c|}
\hline \multirow{2}{*}{ Strain } & \multicolumn{5}{|c|}{ Phage } \\
\hline & T4amB17 & T4amE605 & T4am H39X & T4amN65 & $\lambda$ gam-210 \\
\hline $\begin{array}{l}\left.\text { GM1 (supE44 trm }{ }^{+}\right) \\
\text {GM18 (supE44 trm B1) }\end{array}$ & $\begin{array}{l}1.0 \\
1.0\end{array}$ & $\begin{array}{c}1.0 \\
5 \times 10^{-3}\end{array}$ & $\begin{array}{c}1.0 \\
8 \times 10^{-3}\end{array}$ & $\begin{array}{l}1.0 \\
1.0\end{array}$ & $\begin{array}{l}1.0 \\
<10^{-3}\end{array}$ \\
\hline
\end{tabular}


TABLE 5. Methyl acceptance of mutant tRNA and $r R N A^{a}$

\begin{tabular}{|c|c|c|c|c|c|c|c|c|c|c|}
\hline \multirow{2}{*}{$\begin{array}{l}\text { Enzyme } \\
\text { fraction }\end{array}$} & \multicolumn{6}{|c|}{ tRNA } & \multicolumn{4}{|c|}{ rRNA } \\
\hline & GM1 & GM18 & GM19 & GM23 & $\begin{array}{c}\text { Myco- } \\
\text { plasma }\end{array}$ & $\mathrm{C} 6$ & GM1 & GM18 & GM19 & GM23 \\
\hline $\mathrm{S}-100^{b}$ & 4 & 28 & 15 & 1200 & 1805 & 1035 & 3 & 2 & 1 & 3 \\
\hline Pool I & $\begin{array}{c}(0.002) \\
6\end{array}$ & $\begin{array}{c}(0.017) \\
35\end{array}$ & $\begin{array}{c}(0.009) \\
18\end{array}$ & $\begin{array}{c}(0.72) \\
151^{c}\end{array}$ & $\begin{array}{c}(1.09) \\
931^{c}\end{array}$ & $\begin{array}{c}(0.62) \\
1062\end{array}$ & & & & \\
\hline & $(0.004)$ & $(0.021)$ & $(0.011)$ & $(0.091)$ & $(0.56)$ & $(0.64)$ & & & & \\
\hline Pool II & $\begin{array}{c}3 \\
(0.002)\end{array}$ & $\begin{array}{c}3 \\
(0.002)\end{array}$ & $\begin{array}{c}2 \\
(0.001)\end{array}$ & $\begin{array}{r}1178 \\
(0.71)\end{array}$ & $\begin{array}{c}1660 \\
(1.0)\end{array}$ & $\begin{array}{c}946 \\
(0.57)\end{array}$ & & & & \\
\hline
\end{tabular}

${ }^{a}$ Methyl acceptance is expressed as picomoles of $\left[\right.$ methyl $\left.-{ }^{14} \mathrm{C}\right]$ group accepted per absorbancy unit at $260 \mathrm{~nm}$ of tRNA or rRNA after 180 min of incubation at $37 \mathrm{C}$. The numbers in parentheses represent methyl acceptance values alternatively expressed as moles of $\left[\right.$ methyl $\left.-{ }^{14} \mathrm{C}\right]$ group per mole of tRNA. All acceptance values are "plateau" values; i.e., there was no further increase in methyl incorporation with time.

${ }^{b} \mathrm{~A} 100,000 \times \mathrm{g}$ supernatant of a cell extract of GM1. It was not subsequently fractionated on a diethylaminoethyl-cellulose column to give pool I and pool II methylases.

${ }^{c}$ Not plateau values.

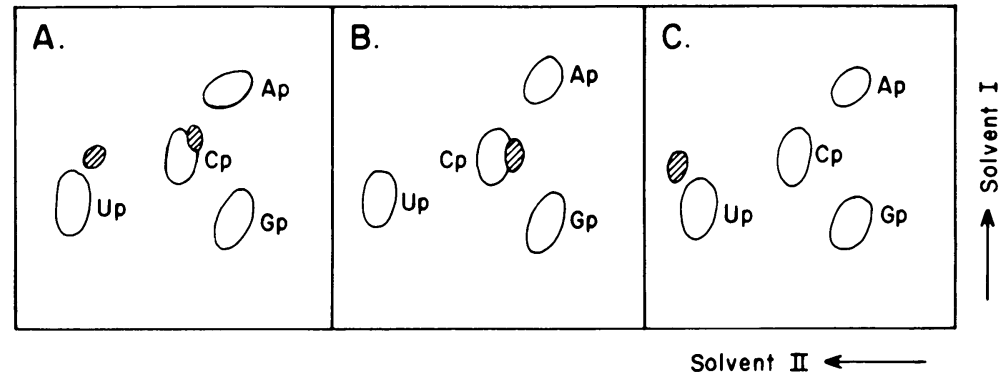

FIG. 2. Two-dimensional thin-layer chromatography of RNase T2 hydrolysates of $\left[\right.$ methyl- $\left.{ }^{14} \mathrm{C}\right] \mathrm{tRNAs.}$. Open circles represent the four major mononucleotides. Hatched areas designate location of the radioactive spots (visualized by radioautography). (A) tRNA from GM18; (B) tRNA from GM19; (C) tRNA from GM23.

was eluted and co-chromatographed in two solvent systems with an authentic marker of 7-methylguanosine 3'-phosphate. Complete coincidence of radioactivity and ultraviolet lightabsorbing material was seen (Table 6). A similar coincidence was seen after enzymatic dephosphorylation and co-chromatography of the resulting methyl- ${ }^{14} \mathrm{C}$-labeled nucleoside with an authentic marker of 7-methylguanosine (Table 6 . The radioactive compound that had a faster mobility in solvent II was redigested with RNase T2 $(24 \mathrm{~h})$. As a result, 70 to $80 \%$ of the radioactivity became associated with 7 -methylguanosine 3 '-phosphate. Thus it appears that under the reaction conditions used, the RNA was only incompletely degraded to 7-methylguanosine 3 '-phosphate. Thus we conclude that strain GM18 is a mutant defective in the synthesis of 7-methylguanosine in tRNA.

As seen from the results of two-dimensional thin-layer chromatography (Fig. 2B), only one methylated nucleotide was released by RNase $\mathrm{T} 2$ digestion of $\left[\right.$ methyl $\left.-{ }^{14} \mathrm{C}\right] \mathrm{tRNA}$ isolated from strain GM19. The relative mobilities of this methylated compound in these two solvent systems suggest that it might be 2-thio-5methylaminomethyluridine 3 '-phosphate. This modified nucleotide occurs in several $E$. coli tRNA species, among them tRNA ${ }^{\mathrm{G}} \mathrm{lu}$ (24). Therefore, we decided to isolate tRNA ${ }^{\mathrm{Glu}}$ from strain GM19 [methyl $\left.-{ }^{14} \mathrm{C}\right]$ tRNA and ascertain that this tRNA carries a radioactive methyl group. Utilizing the principle of complementary anticodon:anticodon interaction between two tRNA molecules, tRNA ${ }^{\mathrm{Glu}}$ can be readily purified by affinity chromatography on polyacrylamide-bound yeast tRNA ${ }^{\text {Phe }}(10)$. For easier analysis, this experiment was performed with tRNA aminoacylated with radioactive glutamate. When $\left[\right.$ methyl $\left.-{ }^{14} \mathrm{C}\right]-\left[{ }^{3} \mathrm{H}\right]$ glutamyl-tRNA from strain GM19 was passed over the tRNA ${ }^{\mathrm{Ph}}$ affinity column (Fig. 3A), only $7 \%$ of the ultraviolet light-absorbing material was retarded, but it contained most of the tRNA Glu (indicated by ${ }^{3} \mathrm{H}$ radioactivity) and the bulk of the methylated tRNA (indicated by the ${ }^{14} \mathrm{C}$ radioactivity). 
TABLE 6. $R_{f}$ values of authentic and biosynthesized nucleotides and nucleosides ${ }^{a}$

\begin{tabular}{|c|c|c|c|c|c|c|}
\hline \multirow{2}{*}{ Strain } & \multirow{2}{*}{ Compound $^{b}$} & \multicolumn{4}{|c|}{$R_{f}$} & \multirow{2}{*}{$\begin{array}{c}\text { Electrophoresis at } \\
\mathrm{pH} 7.0 \\
\text { (cm from origin) }\end{array}$} \\
\hline & & Solvent I & Solvent II & Solvent III & Solvent IV & \\
\hline GM18 & $\begin{array}{l}{ }^{14} \mathrm{C} \text {-labeled nucleotide } \\
\mathrm{m}^{7} \mathrm{Gp} \text { marker } \\
{ }^{14} \mathrm{C} \text {-labeled nueleoside } \\
\mathrm{m}^{7} \mathrm{G} \text { marker }\end{array}$ & $\begin{array}{l}0.65 \\
0.65 \\
0.64 \\
0.64\end{array}$ & $\begin{array}{l}0.49 \\
0.49 \\
0.26 \\
0.26\end{array}$ & & & $\begin{array}{l}(+) 2.2 \\
(+) 2.2 \\
(-) 1.1 \\
(-) 1.1\end{array}$ \\
\hline GM19 & $\begin{array}{l}{ }^{14} \mathrm{C} \text {-labeled nucleotide } \\
\text { Sp marker } \\
{ }^{14} \mathrm{C} \text {-labeled nucleoside } \\
\mathrm{S} \text { marker }\end{array}$ & $\begin{array}{l}0.59 \\
0.59 \\
0.71 \\
0.71\end{array}$ & $\begin{array}{l}0.47 \\
0.47 \\
0.25 \\
0.25\end{array}$ & & & \\
\hline GM23 & $\begin{array}{l}{ }^{14} \mathrm{C} \text {-labeled nucleotide } \\
\text { rTp marker } \\
{ }^{14} \mathrm{C} \text {-labeled nucleoside } \\
\text { rT marker }\end{array}$ & $\begin{array}{l}0.43 \\
0.43\end{array}$ & $\begin{array}{l}0.76 \\
0.76\end{array}$ & $\begin{array}{l}0.56 \\
0.56\end{array}$ & $\begin{array}{l}0.52 \\
0.52\end{array}$ & \\
\hline
\end{tabular}

${ }^{a}$ Thin-layer chromatography and thin-layer electrophoresis were performed as described in Materials and Methods. Unlabeled nucleotides and nucleosides were detected by their ultraviolet absorbance at $260 \mathrm{~nm}$. Radioactive compounds were localized by autoradiography.

${ }^{b} \mathrm{Sp}$, 2-thio-5-methylaminomethyluridine 3'-phosphate; S, 2-thio-5-methylaminomethyluridine; rTp, ribothymidine $3^{\prime}$-phosphate; rT, ribothymidine.

Fom the amount of radioactivity (corrected for double-label settings), one can calculate that there are 0.5 to $0.8\left[{ }^{14} \mathrm{C}\right.$ ]methyl groups per mol of $\left[{ }^{3} \mathrm{H}\right]$ glutamyl-tRNA. To eliminate any doubts about the nonidentity of the ${ }^{3} \mathrm{H}$ - and methyl $-{ }^{14} \mathrm{C}$-labeled material, this enriched fraction of glutamyl-tRNA was subjected to reversed-phase chromatography (Fig. 3B). The ${ }^{14} \mathrm{C}$ and ${ }^{3} \mathrm{H}$ radioactivities were eluted together. This strongly supports the idea that the $\left[{ }^{3} \mathrm{H}\right]$ Glu-tRNA became methylated in vitro. To characterize the methylated nucleotide, the tRNA ${ }^{\mathrm{Glu}}$ was recovered from RPC-5 column fractions, discharged of its ${ }^{3} \mathrm{H}$ amino acid, and then digested with RNase T2. The resulting radioactive methylated nucleotide cochromatographed in the standard two-dimensional system with the authentic marker (Table 6). This was confirmed by co-chromatography at the nucleoside level (Table 6). We conclude that the methyl deficiency of GM19 tRNA, and in particular of tRNA ${ }^{\text {Giu }}$, lies in the undermethylation of the 2-thio-5-methylaminomethyl uridine moiety.

The RNase T2 digest of [methyl $\left.-{ }^{14} \mathrm{C}\right] \mathrm{tRNA}$ from strain GM23 showed only one radioactive spot on the autoradiogram (Fig. 2C). This radioactive compound was at the position where ribothymidine $3^{\prime}$-phosphate is normally found (Table 6). After elution from the chromatogram, this radioactive material, together with authentic ribothymidine, was dephosphorylated and then subjected to thin-layer chromatography in solvents III and IV. In both cases, the radioactive material co-chromatographed with the unlabeled ribothymidine. Thus, we conclude that strain GM23 is a mutant defective in the synthesis of ribothymidine in tRNA.

\section{DISCUSSION}

Although the in vitro screening method used in this work is undoubtedly tedious, the successful isolation of three tRNA methylase mutants shows that it is sensitive enough to detect even mutants that are deficient in only one methyl group per 100 tRNA molecules (e.g., GM19). Therefore further screening, especially of conditional mutants, may lead to the isolation of additional tRNA methylase mutants.

From the initial mapping data of the trm loci, it is clear that the genes for tRNA methylases are scattered over the $E$. coli chromosome. This situation is also found with the genes for tRNA $(28,29)$ and for aminoacyl-tRNA synthetases (31).

The fact that the tRNA in two of the three mutant strains is very little undermodified merits further discussion. In the case of 2-thio-5-methylaminomethyluridine, probably $10 \%$ of the total tRNA species harbor this compound in the anticondon (23). 7-Methylguanosine is always located in the middle of the very short extra loop in perhaps $20 \%$ of the tRNA species. However, the tRNA isolated from mutant cells (GM18 and GM19) grown 

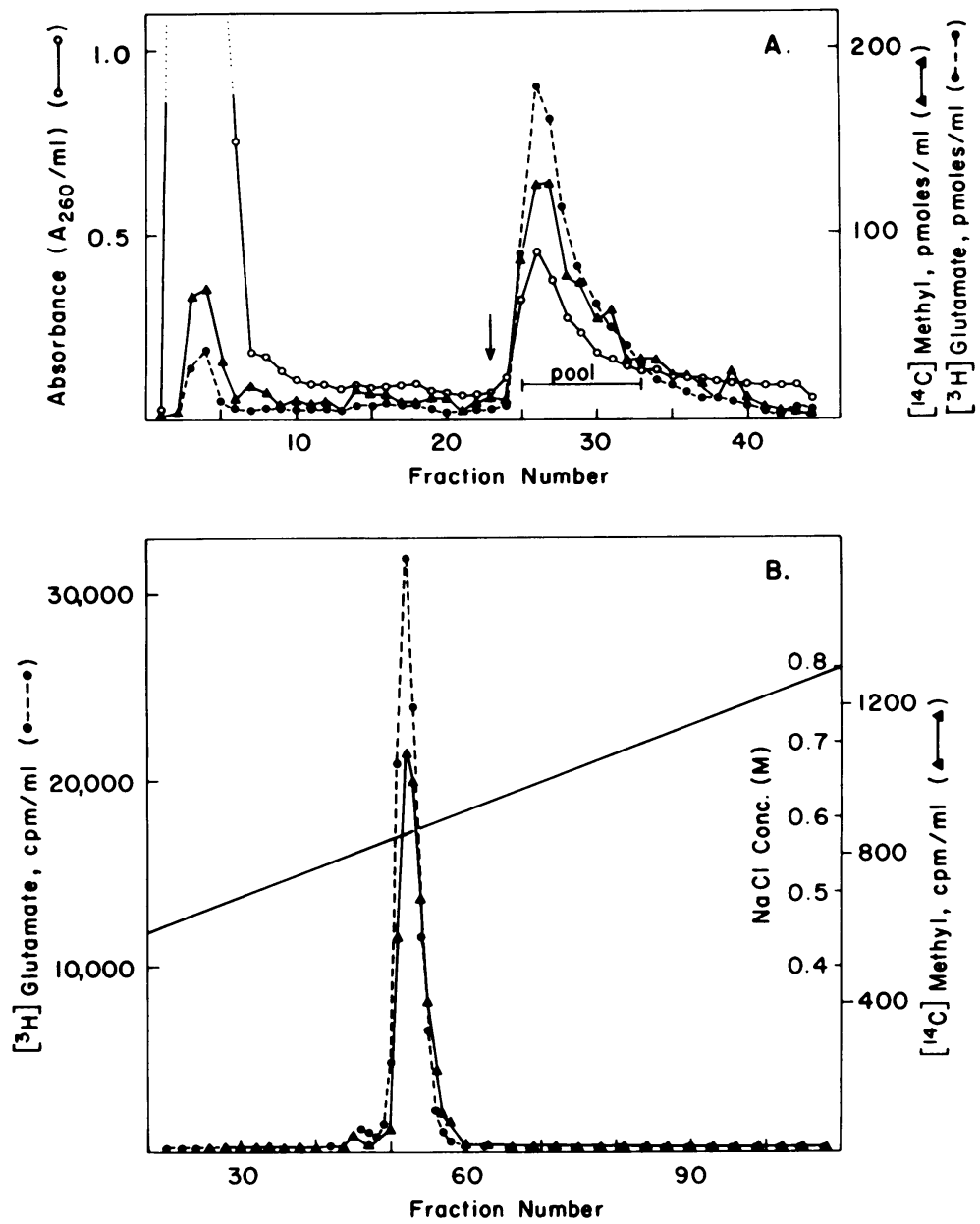

Fig. 3. (A) Affinity chromatography of [methyl $\left.-{ }^{14} \mathrm{C}\right]-\left[{ }^{3} \mathrm{H}\right]$ glutamyl-tRNA from GM19 on a column of

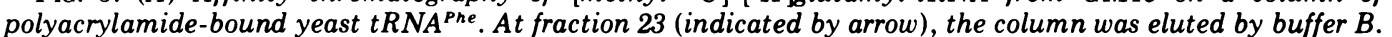
For details, see Materials and Methods. (B) Reversed-phase (RPC-5) column chromatography of [methyl-1" $C$ ]$\left.{ }^{3} \mathrm{H}\right] \mathrm{glutamyl}-\mathrm{tRNA}$ from GM19. For details, see Materials and Methods.

under normal conditions is found to be undermodified only to $10 \%$ of the expected level. This may suggest that there are several tRNA methylases in $E$. coli, all responsible for the formation of the same methylated nucleoside but specific for different tRNA species. Within such a family of methylases only one would be altered, leaving a particular tRNA species undermodified. To date such a case has not been found among tRNA-modifying enzymes. On the contrary, it is known, for instance, that there is only one enzyme in $E$. coli for the formation of isopentenyladenosine in tRNA (27). Pseudouridine biosynthesis in tRNA is catalyzed by at least two enzymes (6). However, even in this case there is only one activity responsible for each site-specific base modification. Another possibility seems at least equally likely: if different tRNA's have different affinities for the tRNA methylases and if the enzymes are only partially active (as in our case), they might modify first those tRNA's for which they have the highest affinity and not modify those for which they have the lowest affinity. We know, for instance, that the 7-methylguanosine deficiency does not occur in tRNA ${ }^{\text {Phe }}$, since this tRNA had been purified from $\left[\right.$ methyl $-{ }^{14} \mathrm{C}$ ]tRNA of GM18 by affinity column chromatography (10) on a tRNA ${ }^{\text {Glu }}$ column, and it was not methyl $-{ }^{14} \mathrm{C}$ labeled (data not shown). Only further genetic characterization of the mutant locus and biochemical identification of the undermodified species will clarify this situation.

It is most important, of course, to find out whether there are any physiological effects caused by the genetic lesion. The finding that 
strain GM18 is incapable of allowing the supE suppressor to function efficiently with certain $\mathrm{T} 4$ or $\lambda$ phage amber mutants, although the wild-type GM1 strain does so, is very exciting and might point the way to further investigations on the involvement of tRNA and the role of methylated bases in the expression of the suppression phenomenon. However, it cannot yet be ruled out that this effect is the consequence of a second mutation that may have been introduced into GM18 by the nitrosoguanidine mutagenesis (11).

\section{ACKNOWLEDGMENTS}

We are indebted to Gail Theall for her help with the nucleotide analysis, to $H$. Grosjean for the preparation of the affinity columns, and to John $K$. Chin for his help in the transduction experiments.

This work was supported by Public Health Service grants GM15401 (from the National Institute of General Medical Sciences) and CA10665 (from the National Cancer Institute), by grant GB36009X from the National Science Foundation, and by a Lilly Karoline Altman Memorial Grant for Cancer Research (P-575) from the American Cancer Society.

\section{LITERATURE CITED}

1. Adams, M. H. 1959. Bacteriophages. Interscience Publishers Inc., New York.

2. Adelberg, E. A., and S. Burns. 1960. Genetic variation in the sex factor of Escherichia coli. J. Bacteriol. 79:321-330.

3. Adelberg, E. A., M. Mandel, and G. C. C. Chen. 1966. Optimal conditions for mutagenesis by $\mathrm{N}$-methyl-N'nitro-nitrosoguanidine in Escherichia coli K12. Biochem. Biophys. Res. Commun. 18:788-795.

4. Björk, G. R., and L. A. Isaksson. 1970. Isolation of mutants of Escherichia coli lacking 5-methyluracil in transfer ribonucleic acid or 1-methyl-guanine in ribosomal RNA. J. Mol. Biol. 51:83-100.

5. Björk, G. R., and F. C. Neidhardt. 1971. Analysis of 5-methyluridine function in transfer RNA of Escherichia coli. Cancer Res. 31:706-709.

6. Cortese, R., H. O. Hammen, S. J. Spengler, and B. N. Ames. 1974. Biosynthesis of pseudouridine in transfer ribonucleic acid. J. Biol. Chem. 249:1103-1108.

7. Epstein, R. M., A. Balle, C. M. Steinberg, E. Kellenberger, E. Boy de la Tour, R. Chevalley, R. S. Edgar, M. Susman, G. M. Denhardt, and A. Lielausis. 1963. Physiological studies of conditional lethal mutants of bacteriophage T4D. Cold Spring Harbor Symp. Quant. Biol. 28:375-392.

8. Fareed, G. C., and C. C. Richardson. 1967. Enzymatic breakage and joining of deoxyribonucleic acid. II. The structural gene for polynucleotide ligase in bacteriophage T4. Proc. Natl. Acad. Sci. U.S.A. 58:665-672.

9. Fleissner, E., and E. Borek. 1963. Studies on the enzymatic methylation of soluble RNA. I. Methylation of the S-RNA polymer. Biochemistry 2:1093-1100.

10. Grosjean, H., C. Takada, and J. Petre. 1973. Complex formation between transfer RNAs with complementary anticodons: use of matrix bound tRNA. Biochem. Biophys. Res. Commun. 53:882-893.

11. Guerola, N., J. L. Ingraham, and E. Cerda-Olmedo, 1971. Induction of mutations by nitrosoguanidine. Nature (London) New Biol. 230:122-125.

12. Hall, R. H. 1971. The modified nucleosides in nucleic acids. Columbia University Press, New York.

13. Harris, C. L., E. B. Titchener, and A. L. Cline. 1969 Sulfur-deficient transfer ribonucleic acid in a cysteinerequiring "relaxed" mutant of Escherichia coli. J.
Bacteriol. 100:1322-1327.

14. Johnson, L., H. Hayashi, and D. Söll. 1970. Isolation and properties of a transfer RNA deficient in ribothymidine. Biochemistry 9:2823-2831.

15. Kelmers, A. D., and D. E. Heatherly. 1971. Columns for rapid chromatographic separation of small amounts of tracer-labeled transfer ribonucleic acids. Anal. Biochem. 44:486-495.

16. Kerr, S. J., and E. Borek. 1972. The tRNA methyltransferases. Adv. Enzymol. 35:1-27.

17. Low, K. B. 1972. Escherichia coli K-12 F-prime factors, old and new. Bacteriol. Rev. 36:587-607.

18. Luria, S. E., and J. W. Burrows. 1957. Hybridization between Escherichia coli and Shigella. J. Bacteriol. 74:461-476.

19. Marinus, M. G. 1973. Location of DNA methylation genes on the Escherichia coli K12 genetic map. Mol. Gen. Genet. 127:47-55.

20. Marinus, M. G., and N. R. Morris. 1973. Isolation of deoxyribonucleic acid methylase mutants of Escherichia coli K-12. J. Bacteriol. 114:1143-1150.

21. Marmur, J. 1961. A procedure for the isolation of deoxyribonucleic acid from micro-organisms. J. Mol. Biol 3:208-218.

22. Nichols, J. L., and B. G. Lane. 1968. In vitro $\mathrm{O}^{21}$-methylation of sugars in $E$. coli RNA. II. Methylation of ribosomal and transfer RNA by homologous methylases in crude cell-free extracts and particulate suspensions from a relaxed mutant of $E$. coli. Can. J. Biochem. 46:1487-1495.

23. Nishimura, S. 1972. Minor components in transfer RNA: their characterization, location, and function. Progr. Nucleic Acid Res. Mol. Biol. 12:49-85.

24. Ohashi, Z., F. Harada, and S. Nishimura. 1972. Primary sequence of glutamic acid tRNAII from Escherichia coli. FEBS Lett. 20:239-241.

25. Phillips, J. H., and K. Kjellin-Straby. 1967. Studies on microbial ribonucleic acid. IV. Two mutants of Saccharomyces cerevisiae lacking $\mathrm{N}^{2}$-dimethylguanine in soluble ribonucleic acid. J. Mol. Biol. 26:509-518.

26. Schaefer, K. P., S. Altman, and D. Söll. 1973. In vitro nucleotide modification of the $E$. coli tRNA ${ }^{\mathrm{T}}$ yr precursor. Proc. Natl. Acad. Sci. U.S.A. 70:3626-3630.

27. Schaefer, K. P., and D. Söll. 1974. New aspects in tRNA biosynthesis. Biochimie 56:795-804.

28. Shimura, Y., and H. Ozeki. 1973. Genetic study on transfer RNA. Adv. Biophys. 4:191-226.

29. Smith, J. D. 1972. Genetics of transfer RNA. Annu. Rev. Genet. 6:235-256.

30. Söll, D., J. D. Cherayil, and R. M. Bock. 1967. Studies on polynucleotides. LXXV. Specificity of tRNA for codon recognition as studied by the ribosomal binding technique. J. Mol. Biol. 29:97-112.

31. Söll, D., and P. Schimmel. 1974. Aminoacyl-tRNA synthetases, p. 489-538. In P. Boyer (ed.), The enzymes, vol. 10. Academic Press Inc., New York.

32. Taya, Y., and S. Nishimura. 1973. Biosynthesis of 5 methylaminomethyl-2-thiouridylate. I. Isolation of a new tRNA-methylase specific for 5-methylaminomethyl-2-thiouridylate. Biochem. Biophys. Res. Commun. 51:1062-1068.

33. Taylor, A. L., and C. D. Trotter. 1972. Linkage map of Escherichia coli strain K-12. Bacteriol. Rev. 36:504-524.

34. Yang, S., E. R. Reinitz, and M. L. Gefter. 1973. Role of modification in tyrosine transfer RNA. II. Ribothymidylate-deficient tRNA. Arch. Biochem. Biophys. 157:55-62.

35. Zissler, J., E. R. Signer, and F. Schaefer. 1971. The role of recombination in growth of bacteriophage lambda. I. The gamma gene, p. 455-475. In A. D. Hershey (ed.), The bacteriophage lambda. Cold Spring Harbor Laboratory, Cold Spring Harbor, New York. 